\title{
Defending broad neutrality
}

\author{
Jeffrey W. Howard ${ }^{1}$ \\ Department of Political Science, University College London, UK
}

\begin{abstract}
This paper interrogates Cécile Laborde’s account of the proper role of religion in the liberal state. It begins by examining Laborde's claims that prevailing liberals are not committed to broad neutrality about the good, but rather only restricted neutrality about the good-and that they are right to do so. It argues against Laborde on both exegetical and substantive grounds. It then turns to Laborde's minimalist conception of secularism, according to which the state must be justifiable, inclusive, and limited, and it argues that it is not sufficiently demanding. Finally, it argues that the classical liberal presumption of skepticism toward religious establishment is warranted.
\end{abstract}

\section{KEYWORDS}

Broad neutrality; restricted neutrality; natural duty of justice; secularism; religious establishment.

\section{Introduction}

Cécile Laborde's powerful new work, Liberalism's Religion, challenges liberal political philosophers to rethink our complacent assumptions about the restricted place of religion in a just society. Pace prevailing wisdom, Laborde contends that the familiar hostility of liberal egalitarians to religion in politicsand to religious establishment in particular-is misplaced. That hostility, she argues, is fueled by a seemingly attractive but pernicious myth at the very heart

\footnotetext{
1 jeffrey.howard@ucl.ac.uk
} 
of liberal political philosophy: namely, that the state ought to be neutral toward all questions of value that lie beyond political justice. In Chapter 3 of the book, she exposes the myth for what it is, showing that some of the most important liberal egalitarians are not, in fact, committed to this thesis. In Chapter 4 , she traces the implications of that finding for the role of religion in public affairs, contending that the state must be neutral only toward particular features of religion, rather than religion in toto. In so doing, she furnishes a novel conception of what secularism is and what it minimally requires-one compatible with certain forms of religious establishment.

Here my aim is to cast doubt on these particular claims. I begin by examining Laborde's discussion in Chapter 3, raising concerns about the distinction between broad and restricted neutrality as it arises in her discussions of Ronald Dworkin and Jonathan Quong, and suggesting that we should be more sympathetic to broad neutrality than Laborde argues. I then turn to Chapter 4, arguing that Laborde's minimalist conception of secularism-according to which the state must be justifiable, inclusive, and limited-is not sufficiently demanding. My criticism focuses on Laborde's interpretation of what justifiability requires, contending that the idea of accessibility, which is central to her view, has almost no normative significance. I will also reject Laborde's contention that a state with religious establishment could nevertheless qualify as inclusive; in so doing, I defend the classical liberal skepticism toward religious establishment. Ultimately I will suggest that while Laborde is right that certain states with established religions may be legitimate, this is not because the justice of religious establishment is a matter of reasonable disagreement; it is not. 
Rather, it is simply because religious establishment often only qualifies as a mild injustice, and thus does not invalidate the government's right to rule.

\section{Rethinking restricted vs. broad neutrality}

\section{Political liberalism and reasonable disagreement}

A defining feature of liberalism as a political philosophy is its refusal to take a stand on a variety of contested questions-about the meaning of the universe, about the proper purposes of human life, about the existence of God. The government, liberals hold, should be neutral about such vexed matters. So goes the familiar slogan. But what, exactly, is the defining feature of these matters that makes them inappropriate subjects of the state's consideration? In virtue of what is it objectionable for the state to take a stand on them, or justify its laws on their basis?

In Chapter 3 of Liberalism's Religion, Laborde demonstrates that once we press prevailing liberal egalitarian theories on this question, it becomes clear that the aspiration of "state neutrality" toward comprehensive conceptions of value is far more restricted than commonly recognized. The strategy of this chapter involves examining three views within liberal political theory: one by Ronald Dworkin; a second by Christopher Eisgruber and Lawrence Sager; and a third, Rawlsian view, defended by Jonathan Quong. Through a close analysis of their writings, she explores how what may seem like a commitment to a capacious understanding of neutrality only amounts to a far more restricted understanding.

Because Laborde builds her own approach in Chapter 4 out of elements of these three views, it is crucial to examine whether these views are, in fact, 
committed to restricted neutrality rather than broad neutrality. And of course, even if she is right that they are so committed, it remains a further question whether such a commitment is plausible. I want to raise doubts about both issues. First, I'll concentrate on the exegetical issue, before turning to the substantive question. For the sake of space, I'll focus specifically on Laborde's discussion of political liberalism, and especially her claim that political liberalism (as defended by Jonathan Quong) is only committed to restricted neutrality.

Laborde's claim is that Quong's theory “does not successfully rule out moderate perfectionism" (p. 99) - a serious charge indeed, given that his book is entitled Liberalism Without Perfection. In the chapter of Quong's book on which Laborde focuses, the puzzle with which Quong is wrestling is this: if reasonable disagreement about the good life means that we should exclude considerations of the good from public justification, why doesn't reasonable disagreement about justice mean that we should exclude considerations of justice from public justification? Quong's answer invokes a distinction between justificatory disagreements_-in which we are reasonably disagreeing about the implications of a common ideal, such as liberal justice-from foundational disagreementsin which we lack a common basis for justifying our positions (Quong 2010, p. 193).

On the basis of this distinction, Laborde interprets Quong to be committed to the following claim: "The salient feature of ideals about the good is...that they are (epistemically) non-shareable" (p. 97). Laborde's insight is that this is not necessarily the case; it appears that there are some ideals of the good that are shareable and indeed shared. Thus if we are to preserve the idea that 
claims about the good life should be excluded from public justification, the distinction between justificatory and foundational disagreement cannot account for this. ${ }^{2}$

Laborde is right that the distinction between justificatory and foundational disagreement cannot itself account for the broad neutrality of Quong's political liberalism. But this would be a decisive objection to Quong's theory only if its anti-perfectionism depended on this distinction alone. But it manifestly doesn't. ${ }^{3}$ Quong's primary reason for rejecting perfectionism is not the epistemic claim that ideals of the good are not amenable to agreement. Rather, it is the normative claim that imposing ideals of the good through law is incompatible with respect for citizens as free and equal. Specifically, it is incompatible with respect for citizens' second moral power, "the capacity to form, revise, and rationally pursue their own conception of the good" (Quong 2010, p. 101). Perfectionist policies are wrongful because they fail to respect persons' prerogative to pursue their own good in their own way. Specifically, Quong argues that perfectionist policies are wrong because they are paternalistic: they hinge on "a negative judgement about the ability of others to run their own lives" (2012, p. 74). This argument simply does not presuppose the previous epistemic argument, even if it is consistent with it. ${ }^{4}$

\footnotetext{
${ }^{2}$ Quong recognizes the possibility of deep agreement among citizens about the good life (2010, p. 254), but does not think this possibility has the implications Laborde argues it does.

${ }^{3}$ See also Quong 2012, p. 56. Laborde appears to recognize this on p. 130, note 44. But this deflates the force of her criticism.

${ }^{4}$ As others have argued, one can reject the burdens of judgement with respect to questions of the good life-since one believes one's preferred comprehensive doctrine is obviously correctand still be wholeheartedly committed to the idea that individuals have the moral right to decide their own paths in life for themselves. See, for example, Wenar 1995, pp. 41-48, and Nussbaum 2011, p. 20.
} 
Quong has a further reason for rejecting perfectionism, even of a moderate variety. Such legislation is wholly unrelated to the moral aims that justify the state's authority in the first place. On Quong's view, the justification of state authority is the natural duty of justice, and the state secures its legitimacy from the way in which it enables citizens to satisfy the duties of justice they owe to others (2012, pp. 126ff). An authority so conceived simply lacks the prerogative to make and enforce laws that help people live better lives.

Quong could, of course, help himself to an alternative theory of state authority that is, in principle, amenable to the idea that a central purpose of government is to help people lead good lives. ${ }^{5}$ But that theory would be precisely the perfectionist, service conception of authority defended by Joseph Razprecisely the view that Quong's book aims to defeat. So the only way for Quong to accept that the state has the right to enforce moderate perfectionist policies is to alter his fundamental theory of state authority. And if he were to do that, he would cease, following Raz, to be even a defender of restricted neutrality; he'd have to give up on neutrality altogether. That is the logical implication of Laborde's criticism of Quong. Because it is an implausible implication, it raises the question of whether we can interpret Quong in a better way-one that enables him to resist the specter of perfectionism. I have argued that we can.

Thus even if citizens broadly agree about a common justificatory framework about the good-even if they discover that they share a common ethical commitment about what a good life involves-this alone does not make

\footnotetext{
5 This is, of course, incompatible with the Dworkinian view that Laborde also endorses-but this just goes to show the difficult
} 
it justifiable to impose it through law. ${ }^{6}$ The point of state power is not to improve citizens' conformity with their own good. It is to enable them to discharge their natural duties of justice.

In sum, while Laborde is right that the distinction between justificatory and foundational disagreement has limited significance, it does not therefore follow that political liberals must accept moderate perfectionism. Indeed, I believe this shows that political liberals would do well to ground their antiperfectionism in the ideals of freedom and equality, and of respect for the two moral powers, rather than in the nature of different kinds of disagreement. Quong needlessly invites Laborde's attack by emphasising the latter.7

\section{Personal ethics and impersonal value}

Suppose, however, that Laborde is right: prevailing versions of liberalegalitarianism, when scrutinized, only require moderate perfectionism. Still, it is worth inquiring what should follow from that conclusion. Even if Laborde is right as a matter of exegesis, it remains a further question whether moderate perfectionism is plausible. So consider another thinker that Laborde examines:

\footnotetext{
${ }^{6}$ It might be replied that it is justifiable if there is genuine consensus on it. This is unlikely, given the burdens of judgment, but let's suppose it's possible. Even so, there are two Rawlsian replies. First, we must view ourselves as possessing the prerogative to alter our views about the good life. Even if it would be permissible for me to create a mechanism whereby I am threatened with punishment unless I comply with my own preferred conception of the good life-as an act of self-binding-it would be wrong of me to insist that others undertake similar self-binding. A society in which citizens remain free to alter their conception of the good life does not use its criminal law to enforce conformity with a particular conception, even if the conception that is presently popular. Second, and more controversially, the state has a duty to ensure that children are free to select whatever justice-consistent conception of the good they choose when they become adults; a society that has selected its preferred conception of the good and crafted its basic structure along its lines arguably contravenes this duty.

${ }^{7}$ His comments on the possibility of a moderate perfectionism, in particular, court this attack (2012, pp. 215ff)—in my view, unnecessarily.
} 
Ronald Dworkin. As Laborde shows, Dworkin believes that the state should be neutral toward competing conceptions of personal ethics: "convictions about the importance of human life or of achievement in human life" (2008, p. 71). Convictions about "impersonal value"-about the intrinsic value of forests, or artwork, or knowledge itself-are perfectly acceptable bases for state action. The claim that Dworkin is committed to restricted, rather than broad neutrality, rests precisely upon this distinction.

Is this actually a plausible distinction? Let us grant that Laborde succeeds in making the exegetical point that this was, in fact, Dworkin's distinction (pp. 76-77). But given that Laborde embraces it for the purposes of her definition of a limited state in Chapter 4 , it is not enough that this be the exegetically accurate interpretation of Dworkin. The distinction needs to survive scrutiny. I doubt that it does. Consider the idea that the state should fund opera. Why should it fund opera? One possibility is to appeal straightforwardly to the principle that opera is intrinsically valuable (say, in virtue of the way in which it powerfully harnesses music to explore important questions in the human experience). But a second possibility is to appeal to the principle that one ought to appreciate opera because it is intrinsically valuable. The first is a statement of impersonal, intrinsic value; the second is a statement of what people ought to do in order to live the kind of life that responds to intrinsic value in the world. Are these statements really so different? Note that the second statement does not reduce opera to something an agent should do to increase her own utility. It is a statement about how a proper human life, one responsive to the value in the world, should be lived. 
Indeed, most conceptions of the good have this feature; most are accounts of what has value in the world and how we ought to respond to that value.

Is Laborde actually convinced that there is a crucial difference between these two principles? I cannot see what the crucial difference is; the second seems plainly entailed by the first. If Laborde is prepared to give Dworkin's distinction between "ethical convictions that are central to personality, like convictions about abortion, and other convictions, that...are not" (2004, p. 358) the pivotal role that she does toward the end of Chapter 4 , we need a more robust defense of it than Dworkin provides.

\section{Rethinking religious establishment}

Laborde believes that moderate perfectionism is acceptable at the bar of liberal justice. Because she believes that, she believes that some forms of religious establishment are acceptable. I now want to argue that even if we grant that moderate perfectionism can be acceptable (setting aside my scepticism so far), we should retain the conventional liberal hostility toward religion in public lifespecifically, hostility toward the use of exclusively religious arguments ${ }^{8}$ in public justification, and toward religious establishment.

In Chapter 4, Laborde advances the argument that "when religious ideas and practices do not meet the features that make state establishment impermissible, then the state may endorse and affirm them" (p. 115). Religious

\footnotetext{
${ }^{8}$ By "exclusively religious arguments," I mean arguments that do not have a public analogue, as per Rawls's famous proviso in Rawls 1997, pp. 783-784. By public analogue, I do not simply mean an argument that is "accessible" in Laborde's highly minimal sense. Following Rawls, an argument is public when it is cast in terms of one of the members of the family of reasonable political conceptions of justice.
} 
ideas and practices are inappropriate in public life when they are inaccessible, divisive, or comprehensive. Conversely, religious ideas and practices can be fully appropriate so long as they do not compromise the state's status as justifiable, inclusive, or limited. Laborde thus concludes:

There is more variation in legitimate state-religion relationships than liberal egalitarians have recognized...Symbolic recognition of religion, conservative laws in matters of bio-ethics, religious accommodations from general laws, and religious references in public debate are not incompatible with minimal secularism and liberal legitimacy (pp. 116117).

This does not, she thinks, mean that the best theory of liberal justice will endorse such policies. Her point, instead, is that there can be "reasonable disagreement" about such matters (p. 153).

I want to criticize this position by scrutinising the first two components of Laborde's conception of minimal secularism: first, the idea that a secular state must be justifiable; and second, the idea that a secular state must be inclusive.

\section{The justifiable state}

A state, Laborde contends, must be justifiable to those it governs. But what does justifiability mean? Laborde's strategy in this chapter is to take the basic impulses of the liberal views surveyed in Chapter 3 to construct her own vision of what liberal justice minimally requires. The idea that a liberal state must be justifiable is evidently inspired by Quong's Rawlsian view. But Laborde deviates from this 
view substantially, and in ways that render her position less plausible than it could be.

Steering a middle course between the requirement that reasons for coercive laws be intelligible to all those coerced, and the requirement that reasons for coercive laws be endorsed (and thus shared) by all those coerced, Laborde defends the proposal that reasons for coercive laws be accessible to all those coerced. She argues that accessible reasons are reasons that "can be understood and assessed, but need not be endorsed according to common standards" (p. 120). 9 By making accessibility the defining virtue of public deliberation, Laborde defends what she calls "a thinly epistemic theory of public reason" (p. 119).

Why is accessibility normatively significant? Laborde argues that the state perpetrates what she describes as an "epistemic wrong" (p. 118) when it coerces citizens "in the name of reasons that they do not understand and cannot engage with". In such cases, "they are not respected as democratic reasoners" (p. 118). But why? Consider two cases. In the first case, a fanatic proposes a law that would execute all members of my ethnic group, on the grounds that she has had a personal revelation from God enjoining her to do so. In the second case, a fanatic proposes the same law me on the grounds that she has a moral duty to protect the political community by eliminating dangerous elements, which she has determined by working through arguments about the

\footnotetext{
9 See further discussion in Vallier and D'Agostino 2014. Note that Laborde's definition of intelligibility appears weaker than Vallier and D'Agostino's. For them, “A's reason $R_{A}$ is accessible to the public if and only if all members of the public regard $\mathrm{R}_{\mathrm{A}}$ as justified for A according to common evaluative standards." I believe my objection would stand even if Laborde employed Vallier and D'Agostino's definition, but it would require some modification.
} 
demands of her religion's holy book. Let's grant that she wrongs me, all-thingsconsidered, in both cases—something Laborde would obviously accept. Laborde nevertheless seems to think that the first case is worse, since the reasons are not accessible to me; in this case, I cannot understand and assess her reasons for acting. The epistemic inaccessibility, Laborde thinks, wrongs me epistemically. Thus while I have a complaint, at least in the second case I can say: "I'm about to be murdered—but at least I'm being respected as a democratic reasoner!"

This strikes me as unpersuasive. What difference does it really make that the wrongdoer's reasons are accessible? Note that Laborde places no substantive, moral constraints on what counts as accessible; it is a wholly epistemic criterion. Thus reasons derived from New Natural Law are accessible since they are "based on inferences that require no appeal to special knowledge such as divine revelation" (p. 127). But-to change the example-I cannot see what difference this epistemic fact should make to a gay citizen about to be imprisoned for violating conservative sexual rules. What difference does it make whether the state is imprisoning him because of inaccessible divine revelation, or fully accessible inference on the basis of some manifestly mistaken but nevertheless comprehensible piece of reasoning? It's all injustice to him.

Laborde anticipates this worry by noting that the accessibility condition is simply "an epistemic constraint on the inputs of public debate" — so while it is necessary, it "is not a sufficient condition of liberal legitimacy" (p. 129). But what I question is why it should be listed as a separate condition at all. Why 
does Laborde think it is even pro tanto wrong to coerce a person on basis of beliefs that are inaccessible? Laborde notes that the accessibility condition "identifies what kinds of reasons can enter the 'permissibility pool' but does not specify which reasons are conclusive enough to provide a full justification for public policy and law" (p. 130). But why is it permitted in the pool to begin with? The idea seems to be motivated, of course, by the conviction that there is something additionally wrong about coercing someone on the basis of reasons (s)he cannot even comprehend. Yet my example cases raise doubts about precisely that point. The arguments in Mein Kampf are publicly accessiblethey are not based on revelation or testimony. But this fact seems to make no difference at all to whether they ought to be part of the "permissibility pool." If the permissibility pool is so broad as to include all this, accessibility is reduced to a trivial precondition (just as "All reasons must be explicable using human language" would be a trivial precondition). The normative significance of this epistemic condition is thus minimal at best, nonexistent at worst. ${ }^{10}$

Laborde could well reply that it would be a serious cost to her theory to eliminate talk of accessibility. But there is a serious question as to whether she needs it at all. My own suggestion to her is that the justifiability condition of a

\footnotetext{
${ }^{10}$ Two reviewers helpfully suggest that these examples concern cases in which the policy in question is obviously wrong. If we consider cases in which the policy is permissible, but the proffered justification is inaccessible, we might think that there is, in fact, a separate, epistemic wrong at work. For example, suppose that a just environmental policy is justified by a speaker on the grounds that his deity (whom I do not recognise) enjoins us to protect the planet. Does the speaker thereby disrespect me? I think the answer is no, but precisely because there is a plausible public justification for the policy in question (see note 7). My point is simply that it is implausible to think that an injustice perpetrated on the basis of inaccessible reasons (in Laborde's minimal sense) is worse than an injustice perpetrated on the basis of accessible reasons. The properties that render the policy or conduct wrongful determine the gravity of the wrongness, not the arguments that the wrongdoer utters to rationalise them.
} 
legitimate state—Laborde's first criterion, which she casts the notion of accessibility to play—is simply a function of her second and third criteria (inclusiveness and liberty). In other words: we want an inclusive state—one that supports the civic equality of citizens-and we want a limited state-one that supports the freedom of citizens-and that insofar as the state accomplishes these goals, it is justifiable to them. This is not to say that we should abandon talk of public justification; it is simply to say that public justification is a matter of attunement with the ideals of inclusiveness and liberty. In Rawlsian terms, a policy or argument is publicly justified just in case it expresses respect for citizens as free and equal—as bearers of the two moral powers, who have a claim to fair terms of social cooperation. ${ }^{11}$

\section{The inclusive state}

I now want to examine Laborde's second feature of a secular state. On her view, "[w]hen a social identity is a marker of vulnerability and domination, it should not be symbolically endorsed and promoted by the state" (p. 150). Because religion is not always such a marker, Laborde argues, symbolic recognition of religion cannot be ruled out as incompatible with liberal-egalitarian values. Developing the insights defended by Eisgruber and Sager, Laborde's thesis is that religious establishment is problematic only when it has the effect of

\footnotetext{
${ }^{\text {" }}$ One reviewer notes that a policy might be consistent with liberty and inclusivity, yet fail accessibility - for example, a proposal to fund the arts justified on the basis of the argument that doing so glorifies God. My claim is that so long as the policy can be justified on the basis of a commitment to liberty and inclusivity, the fact that various citizens articulate private comprehensive reasons why they support the policy need not be construed as disrespectful to others, precisely because an argument is available in terms of liberty and inclusivity.
} 
disparaging certain groups and undermining civic equality-perpetrating what Nussbaum calls "expressive subordination" of those who do not share the official religion (2011, p. 135). When it does not do this, however, religious establishment is wholly unproblematic. Laborde thus gives us the example of a hypothetical state-Divinitia. In Divinitia, the government "symbolically recognises one religion, but not in a way that infringes on the equal citizenship of non-adherents" p. 151). So, the state does not award special material benefits to the adherents of that religion, it does not prefer them for public offices, and it does not actively educate schoolchildren to regard the official religion as one they should adopt.

I have two objections to this argument. First, even if is true that there are certain countries-e.g., Madagascar and Senegal (p. 142)—in which religion is not divisive, this is not sufficient to demonstrate that liberals' presumptive skepticism toward religious establishment is unwarranted (as Laborde says it is when criticizing Kymlicka on p. 143). Normative reflection on history gives us excellent reason to be prima facie skeptical of even "merely" symbolic establishment. In the vast preponderance of societies, state recognition of religion is divisive. Insofar as we embrace not simply a liberal but also a republican approach to our institutional design—ensuring that the institutions we create will be robust in their protection of citizens' status as free and equal—we have reasons to worry about the reasons that ordinarily motivate human beings to establish religions.

This objection applies most forcefully to cases in which citizens are offering a new proposal to establish a religion. It is extraordinarily difficult to 
imagine a context in which (a) citizens are so religiously devoted that they insist the state symbolically recognize their religion, and yet in which (b) those who adhered to the religions would be wholly untroubled. Of course, the psychological fact that they are troubled is not sufficient to establish a legitimate complaint. But given the kinds of reasons that have motivated human beings to unite religion and state, ${ }^{12}$ there is excellent reason to conclude that religion is presumptively illegitimate as an object of state symbolic endorsement. ${ }^{13}$ Even granting, then, that it is not necessarily illegitimate, there is a demanding burden of proof required for anyone proposing religious establishment. Religious minorities can be forgiven for worrying whether "merely symbolic" recognition of a majority religion could slip someday into coercive support for that religion.

My second reason for opposing religious establishment is simple, and recalls the argument made in the previous section about political liberalism and state authority. According to numerous liberals, the fundamental justification of the state's authority-and our obligation to obey it-is the natural duty of justice. The state has authority over us, on this view, because by complying with it, we are better positioned to satisfy the duties of justice we owe to others; we better succeed at treating one another as free and equal moral agents. ${ }^{14}$ On a liberal view, the purpose of state authority is TO realize

\footnotetext{
${ }^{12}$ All of which have concerned giving members of the preferred religion a symbolic or material advantage - why would they spend so much energy advocating for establishment of theirr preferred religion if it didn't have this effect?

${ }^{13}$ As one reviewer notes, we might think that a state can symbolically establish a religion without sending the message that it is the correct religion. I find this difficult to accept.

${ }^{14}$ This duty is discussed in Rawls 1999, pp. 99-100, 115, 293-301, and 334, as well as in Waldron 1993 and Stilz 2009. And see Quong 2010, p. 128.
} 
just institutions, which secure citizens with their fair share of liberties and opportunities with which they can then pursue their conceptions of a good life. It rightly engages in coercion for this purpose.

Yet the proposal that the state should take sides in questions of religious truth is unconnected to this purpose, and it is extremely difficult to see how it advances it. In other words: how does the state get the authority to take sides on religious questions? It is difficult to see why citizens would grant the state the authority to expend its symbolic and material resources "taking a stand" on religious matters. Perhaps there are such reasons-for example, by taking a stand on religious questions, then state facilitates religious homogeneity, which in turn stabilizes the regime. This may well be empirically so. But it is difficult to see why citizens who deny the official religion ought nevertheless not be insulted by this—-to view it as a case of "stability for the wrong reasons". Surely they should. Insofar as religious pluralism is the free outcome of reason under free institutions, it is very difficult to see why citizens, viewing one another as free and equal, would nevertheless authorize the state to champion one religion over others.

This all leads to a crucial final point. Intuitively, I think we all should agree with Laborde that Divinitia is, indeed, a legitimate state. But Laborde seems to rely on the popular idea that a state is legitimate if it is regulated by a reasonable conception of justice-a conception within the family of reasonable political conceptions. Laborde's distinctive aim is to show that a reasonable conception of political justice could authorize religious establishment under certain conditions. If the arguments I have advanced are right, I believe we 
should be genuinely skeptical about that. But I think it's still true that a state like Divinitia is legitimate-it retains the right to make and enforce law over its territory-for the simple reason that it is sufficiently just. While it contains injustices, they are not egregious injustices, even if they are nevertheless undeniably unjust by any reasonable view. Divinitia is, in the terminology of The Law of Peoples, a decent society (Rawls 2001). Internal efforts to overthrow the government, or external efforts at regime change, would be morally impermissible. And that's because religious establishment simply need not be considered as heinously unjust as most liberals tend to suggest. The natural duty of justice would enjoin us to continue to support that state and, of course, work to increase its justice. So while religious establishment is, I have argued, likely beyond the pale of reasonable disagreement, a state with it need not be considered illegitimate.

\section{Acknowledgments}

I am grateful to all who participated in our UCL symposium on Liberalism's Religion, especially Aurelia Bardon and Cécile Laborde. I am also indebted to the two referees, whose comments improved this paper greatly.

\section{Disclosure statement}

No potential conflict of interest was reported by the author 


\section{Notes on contributor}

Jeffrey $W$. Howard is Lecturer in Political Theory in the Department of Political Science at University College London. He works on topics including criminal punishment, freedom of expression, and the ethics of counter-terrorism. He has published in The Journal of Political Philosophy, The Journal of Applied Philosophy, Law and Philosophy, Political Studies, Critical Review of International Social \& Political Philosophy, and Criminal Law and Philosophy.

\section{References}

Dworkin, R. 2004. “Ronald Dworkin Replies.” In: J. Burley, Dworkin and his Critics. Oxford: Blackwell

-2006. Is Democracy Possible Here? Princeton: Princeton University Press. 2004 .

Laborde, C. 2018. Liberalism's Religion. Cambridge, MA: Harvard University Press.

Nussbaum, M. 2011. "Political Liberalism and Perfectionist Liberalism.” Philosophy E Public Affairs, 39, 3-45.

Rawls, J. [1971] 1999. A Theory of Justice, revised edition. Cambridge. MA: Harvard 
University Press.

-2001. The Law of Peoples. Cambridge, MA: Harvard University Press.

— [1993] 2005. Political Liberalism. New York: Columbia University Press.

Stilz, A. 2009. Liberal Loyalty: Freedom, Obligation, and the State. Princeton: Princeton University Press.

Quong, J. 2010. Liberalism without Perfection. New York: Oxford University Press.

Quong, J. 2012. “Liberalism Without Perfection: Replies to Gaus, Colburn, Chan, and Bocchiola" Philosophy and Public Issues, 2, 51-79.

Vallier, K. and D'Agostino, F. 2014. "Public Justification.” The Stanford Encyclopedia of Philosophy. Edward N. Zalta (ed.). Stanford, CA: The Metaphysics Research Lab, Stanford University. URL = <https://plato.stanford.edu/archives/spr2014/entries/justification-public/>.

Waldron, J. 1993. "Special Ties and Natural Duties.” Philosophy E Public Affairs, 22, 3-30.

Wenar, L. 1995. “Political Liberalism: An Internal Critique.” Ethics, 106, 32-62. 
